\title{
A Procedural Rationale for the Necessity Defense
}

\author{
Gideon Yaffe
}

Published online: 23 September 2009

(C) Springer Science+Business Media B.V. 2009

\section{Introduction}

The lion comes daily to the library and is beloved by the patrons and by the head librarian, Miss Merriweather. The library has many rules, but only one of them is of particular importance to the lion: no roaring allowed. The penalty for violation, as the lion well knows, is nothing less than excommunication. When Miss Merriweather falls and breaks her arm while reaching to a high shelf, the lion finds that the only way he can get help is to roar. The embittered assistant librarian, Mr. McBee, enforces the rule and the lion has no choice but to leave the library. At this point, the child who is listening to the illustrated book Library Lion, recoils in horror. ${ }^{1}$ How can it be, thinks the child, that someone could be punished for doing what was clearly the best thing to do in the circumstances? The child's horror is reflected in the criminal law in the affirmative defense of necessity, also called the lesser evils defense. A defendant who uses it says that, given the peculiar circumstances he faced, the act for which he is charged with a crime was better, all told, than any alternative. Some patrons are disturbed, to be sure, but Miss Merriweather gets the medical attention she badly needs. Alternatively, to give an example of the sort that actually appears in the law, the defendant trespasses in order to prevent a fire from spreading, arguing that the trespass is much less bad than the fire damage that was thereby prevented.

The affirmative defenses, such as infancy, insanity, public duty, self-defense, and necessity, are ordinarily divided into excuses and justifications. The excuses are typically glossed as instances in which the defendant was not fully responsible for

\footnotetext{
${ }^{1}$ See Michelle Knudsen and Kevin Hawkes, Library Lion (Cambridge, England: Candlewick Press, 2006).

G. Yaffe $(\bowtie)$

School of Philosophy, Mudd Hall, University of Southern California, Los Angeles, CA 90089-0451, USA

e-mail: yaffe@usc.edu
} 
his prohibited behavior, with insanity given as the quintessential example. The justifications are typically glossed as instances in which the conduct in question was not wrongful, with self-defense taken to be paradigmatic. Without exception, theorists classify the necessity defense as a justification. The Model Penal Code follows them in this. ${ }^{2}$ Recently, one prominent commentator has referred to it as "the paradigmatic justification." 3

The consensus view is right this far: the defense cannot be an excuse. Decisive evidence against that possibility is that people who do the best they can are often worthy of praise for such conduct; Miss Merriweather owes the lion thanks. But praiseworthy conduct meets the conditions that excuses show to be absent, since excuses nullify responsibility, regardless of whether what a person is responsible for is good or bad. ${ }^{4}$ Still, despite the merits of the consensus view in this respect, there is reason for a significant revision in our conceptualization of the necessity defense. Despite the fact that it is not an excuse, the necessity defense is also not a justification. The person whose best option is a criminal act does not deflect criminal liability from himself because such acts are not wrongful. Instead, to show that the criminal act was the best of a person's option is to show that the government would be acting hypocritically were it to punish. The child recoils, and we do too, on the view to be defended here, on sensing that the punisher is acting wrongly, and not, in the end, on sensing that the punished has done nothing wrong, even if that is also true.

There is universal agreement that both excuses and justifications are distinct from what are sometimes called procedural defenses or extrinsic policy defenses, with immunities, such as diplomatic immunity, serving as the prime example. ${ }^{5}$ A person who avoids criminal liability through appeal to his diplomatic immunity, and while admitting that he performed the prohibited act with the relevant results, circumstances, and mental states, while admitting that the prima facie case against him has been made, neither claims that he was not responsible for his conduct nor that it was not wrongful. Instead, he avoids criminal liability on the grounds that if the state were to punish him it would be acting in a way, or condoning its acting in a way, that is inappropriate for the state to act. In the case of diplomatic immunity, to punish would be for the state to violate an agreement that it has made with the defendant's nation. When the state recognizes an excuse or a justification it officially recognizes a gap of normative significance between the defendant and the paradigm instance of a person who is rightly punished under the relevant statute for

\footnotetext{
2 See Model Penal Code s. 3.02.

3 Larry Alexander, "Lesser Evils: A Closer Look at the Paradigmatic Justification," Law and Philosophy 24 (2005); also see Mitchell Berman, "Lesser Evils and Justification: A Less Close Look," Law and Philosophy 24 (2005); Kenneth W. Simons, "Exploring the Intricacies of the Lesser Evils Defense," Law and Philosophy 24 (2005); George Fletcher, Rethinking Criminal Law (Oxford: Oxford University Press, 2000), p. 774; Paul Robinson, Criminal Law Defenses (St. Paul: West Press, 1984), p. 4; Glanville Williams, "The Theory of Excuses," Criminal Law Review(1982), p. 732; cf. Michelle R. Conde, "Necessity Defined: A New Role in the Criminal Defense System," UCLA Law Review 29 (1981), p. 413.

4 See Susan Wolf, “Asymmetrical Freedom," The Journal of Philosophy 77 (1980).

5 See Paul Robinson, "Criminal Law Defenses: A Systematic Analysis," Columbia Law Review 82 (1982).
} 
acts like the defendant's. When the state recognizes a procedural defense, by contrast, there is no implication that there is any normatively significant gap of this sort. Our refusal to punish, in such cases, is a rebuke of the state and is consistent with the recognition that the defendant and his act are no different from defendants and their acts envisioned by the state as the proper objects of punishment.

Procedural defenses can be divided into two sorts. The first sort includes defenses in which the government's misconduct, which a guilty verdict would condone, occurred prior to the issuance of the guilty verdict. ${ }^{6}$ Although it is not an affirmative defense but, instead, a tool that can be used to help a defendant, the exclusionary rule is of this first sort. Coerced confessions are inadmissible as evidence because the government's act of coercing the defendant is thought objectionable and would be condoned were the confession admitted. In the second sort of procedural defense, the issuance of the guilty verdict, or the subsequent punishment of the defendant, is objectionable only because it is inconsistent in some way with some prior government conduct with respect to the defendant. We might call such defenses procedural estoppel defenses. ${ }^{7}$ The defense of double jeopardy is of this sort. To complete the prosecution for a crime is to take the question about the defendant's guilt or innocence to be officially and authoritatively settled, and thus to accept that the government has the authority to settle the question. But to try someone for a crime is to imply that the question is not yet settled and that the government has the authority to settle it. Hence, to try someone for a crime with respect to which prosecution was previously concluded is to, at once, accept that the government has the authority to settle the question of guilt and to reject the prior exercise of its authority. These two actions on the part of the government are inconsistent with one another, not in the sense of logical inconsistency but in the sense that they involve the expression of inconsistent commitments about the government's authority, and it is the inconsistency that warrants granting the defense and so thereby avoiding the attribution of criminal liability to the defendant.

As we will see, the necessity defense is a procedural defense of the second sort: it is a procedural estoppel defense. When the elements of a necessity defense are in place, punishment by the state would amount to a form of inconsistency on the state's part. Hence, we refuse to punish when a defendant has a necessity defense as a way of preventing the state from acting inconsistently. Theorists have tended to overlook this point because, in point of fact, most defendants who employ the necessity defense are, indeed, less worthy of punishment than others charged with similar crimes. Still, what will be argued here is that despite initial appearances, to grant a defendant's necessity defense is not to imply that there is any sense in which the defendant or his act is less worthy of punishment than defendants who have acted similarly but not in circumstances of necessity. There may be, in fact there often is, a normative gap between such offenders and those whose necessity defenses are granted, but it is not the presence of such a gap that, in the end, justifies

\footnotetext{
${ }^{6}$ See Gideon Yaffe, “The Government Beguiled Me': The Entrapment Defense and the Problem of Private Entrapment," The Journal of Ethics and Social Philosophy 1 (2005).

7 Thanks are due to Doug Husak for this terminology and for clarifying the distinction in procedural defenses.
} 
the refusal to punish but, instead, the fact that such punishment would involve unacceptable state action.

\section{The Contours of the Necessity Defense}

The necessity defense was constructed by judges who sensed that a defense was appropriate in certain cases despite recognizing that the cases failed to fit the model of any other affirmative defense. In what is perhaps the earliest American case in which the necessity defense was explicitly identified, United States v. Ashton, a ship's crew revolted when they discovered that the ship was not seaworthy, after which the captain refused nonetheless to return to port to make repairs. ${ }^{8}$ The judge in the case created the necessity defense in order to acquit the defendants, writing that it would simply be wrong to punish the defendants for failing to follow an order that would have cost them their lives.

The judge in Ashton explicitly appealed in explanation of his verdict to the fact that what the defendants did was better than the alternative. The necessity defense is unique among criminal defenses in requiring some kind of showing to this effect. A defendant who claims he acted in self-defense, by contrast, compares the act he performed, killing another person, for instance, to the alternative and claims that had he refrained from acting as he did he would have been killed or injured, or at least that he reasonably believed this to be so. There are several other things he must show. He must show, for instance, that the person he killed was the aggressor in the altercation ending in the death; but he is not required to show, or show that he believed, that the act he performed was better than the alternative by any standard. He need not show, for instance, that his life was actually more worthy of being saved than that of the aggressor whom he killed. Nor need he show that unchecked aggression is such a terrible thing as to outweigh other evils realized through his act. The defense of self-defense is available, and should be, to the defendant even if it would be better all told for him to suffer the aggressor's blow rather than defend himself. Similarly, in defense of property, a defendant need not show that there was greater loss promised in not defending his property than in defending it. A person has every right, if he so chooses, to spend a hundred dollars to take back the fifty dollar item of his that another person is possessing and such a right does not require that he believe, or that it be true, that the violation of his right to the fifty dollar item outweighs the financial loss to him in taking it back. The defense is compatible with its being better all told just to let the other person keep the fifty dollar item. The same is true across the board with all the other defenses; they are available to a defendant even if it would have been better in every sense that matters for the defendant not to have acted as he did.

This is not to say that the only thing that a defendant must show to establish the necessity defense is that the alternative to his act was worse. All jurisdictions require more than this for a defense. Most require, for instance, that there was no third and better option; that the greater evils be imminent; and that the defendant not

${ }^{8}$ See 24 F.Cas. 873 (C.C.D. Mass. 1834) (No. 14,470). 
be responsible for the fact that he faces a choice of evils. All of these requirements place restrictions on the defense. They serve to deny the defense to some people who in acting in the way prohibited by a criminal statute nonetheless chose the best of their options. But, still, the defendant who shows that it was better to act as he did than to omit the act has taken the primary step needed for exoneration, even though the defense requires support through a showing that the other elements of the defense are present. This fact itself is in need of a rationale. If the values of the alternatives are irrelevant for every other defense, why are they relevant in the necessity defense?

To answer this question, we need a better sense of what, exactly, the defendant must show to establish the relevant facts about the values of the alternatives. This crucial aspect of the defense is not applied consistently, nor formulated with precision sufficient to rule out substantial variation in its application, in any jurisdiction, including jurisdictions that follow the Model Penal Code. It would be misleading to suggest that there is a settled view of what needs to be shown by a defendant hoping to employ the defense. There are, though, a pair of questions that judges find themselves needing to answer in order to apply the defense. First, judges need to know what standards, or whose standards, to employ in evaluating the alternatives. Second, judges need to know what, exactly, by those standards, needs to be better, or less bad, than what. Let us consider each of these two issues in turn.

Perhaps the one fixed point in thought about the necessity defense is that what the defendant did must have been less bad than the alternative by the legislature's standards. When the legislature's opinion is not clear, the question is to be determined at trial by the judge or the jury. But even in that case, the guiding question is not whether the defendant thinks that what he choose was less bad than the alternative, but whether it was, in fact, less bad independently of what he happens to have thought. It is striking that this position is taken in the Model Penal Code, given the pride of place that it gives to the defendant's mental states in determinations of criminal liability. The default position of the Model Penal Code is that what the defendant thinks is far more important for determining his criminal liability than what is actually the case. But the Model Penal Code departs from this pattern in this case. The commentary reads as follows: "[T]he balancing of evils is not committed to the private judgment of the actor; it is an issue for determination at the trial. Thus, even if the defendant genuinely believes that the life of another is less valuable than his own financial security, his conduct would not be justified [under the necessity defense] for [the defense] requires that the harm or evil sought to be avoided be greater than that which would be caused by the commission of the offense, not that the defendant believes it to be so." 9 The example given here of a person who kills another person in order to prevent his financial ruin and thinks his financial ruin to be far worse than another person's death illustrates the need for appeal to a standard of evaluation other than the defendant's. However, the example has a feature which is not present in the cases that actually test judges' resolve on this issue. In this hypothetical case, the evaluative standard that the imagined defendant accepts, under which his financial ruin is worse than the death of the

${ }_{9}$ Model Penal Code, Commentary, prt. 1, p. 12. 
person he kills, is so far off that anyone who accepted it would be, on those grounds, morally objectionable. In fact, we might even say that the manifestation in action of acceptance of such a standard is what makes some people worthy of punishment. Hence, the attitude might not only fail to exculpate, but might inculpate.

Let us contrast this with, to give just one example, the case of Commonwealth $v$. Leno, in which the defendants distributed clean hypodermic needles to intravenous drug users without prescriptions. ${ }^{10}$ The defendants offered a necessity defense, saying that that the evils of violation in this instance were less than the evils associated with the spread of AIDS. In rejecting the defendants' defense, the court says, "The defendants' argument is that, in their view, the prescription requirement for possession and distribution of hypodermic needles and syringes is both ineffective and dangerous. The Legislature, however, has determined that it wants to control the distribution of drug-related paraphernalia and their use in the consumption of illicit drugs. That public policy is entitled to deference by the courts." ${ }^{11}$ While the court here employs the legislature's standard of evaluation, and hence acts consistently with the advice of the Model Penal Code, the case bears only a formal resemblance to the hypothetical that the commentary of the Model Penal Code uses to illustrate the need for appeal to a standard of evaluation other than the defendant's. After all, there is nothing itself objectionable, considered independently of the legislature's view of the matter, about holding that AIDS is so terrible that it outweigh the risks associated with the distribution of hypodermic needles to individuals who have not been screened to determine that they have a medical need for them. Reasonable and ethically sound people could surely differ on the issue. To accept the standards of evaluation accepted by the defendants is little like acceptance of a standard under which another's death is less bad than your financial ruin. It might be suggested that in cases like Leno, defendants fail to defer as they ought to the demands of the law as such; they fail to take the fact of illegality as reason enough not to do what they did. But while that might be true, it fails to distinguish cases like Leno from cases like Ashton, or any other cases in which the necessity defense is rightly granted. In all such cases, the defendant takes the fact of illegality to be outweighed by other, more pressing considerations.

What needs to be explained is both a negative fact and a positive one. The negative fact is that the defendant's evaluative standards are irrelevant to the evaluation of the alternatives. The positive fact is that the legislature's standards take precedence over any other possible standards that we might invoke. Both of these facts should be explained by a rationale for the necessity defense.

Knowing what standards to employ in evaluating the evils involved in a particular case is not enough to determine if the defendant deserves the necessity defense. We also need to know what is to be evaluated. To see the difficulty in determining this, consider five different things that can be assessed for value, all of which are sufficiently closely associated with the act the defendant actually performed to warrant evaluating the act in light of them, whether or not they are exhaustive. The first is the actual: the state of affairs actually realized by the

\footnotetext{
$\overline{10}$ See 415 Mass. 835, 616 N.E.2d 53 (1993).

11 Ibid.
} 
defendant's conduct. The second is the expected: the state of affairs that at the time of action the defendant believed he would realize by his conduct. The third is the reasonably-expected: the state of affairs that at the time of action a reasonable person would have believed would be realized by acting as the defendant acted. The fourth is the usual: the state of affairs ordinarily actualized by acts relevantly similar to the defendant's. The fifth is the proscribed-to-avoid: the set of states of affairs actualized by acts proscribed by the statute under which the defendant is charged.

The appeal here to states of affairs is not meant to imply that the mode of evaluation that is appropriate to the necessity defense is utilitarian. In fact, nothing about how the acts are to be evaluated is meant to be implied by it. States of affairs can be evaluated hedonistically or through other measures of utility, but they can also be evaluated using the kinds of modes of evaluation preferred by deontologists. Philosophers who hold, for instance, that an act is to be evaluated entirely by appeal to the quality of will of the agent of the act will be solely interested in the actual state of affairs associated with the act, since that state of affairs includes facts about the agent's intentions and aims. Similarly, philosophers interested in rights violations and infringements will be interested in some of these associated states of affairs, and not others, depending on what they understand rights to be. No matter how we evaluate acts, we are bound to be interested in some of these associated states of affairs.

Each of these five different states of affairs is also associated with omission of the act the defendant performed, although the proscribed-to-avoid is the same in either case. It is common enough for the five associated with the act to be different from one another, although they are sometimes the same, and for the four other than the proscribed-to-avoid to be different from the four associated with omission of the act. The defendants in Ashton expected that the ship would sink and they would all drown if they followed the captain's order. That was the expected state of affairs associated with following the order, or equivalently, the omission of the act of refusing to follow the order that the defendants admit having performed. But let us imagine that, in fact, the captain was right and they would have made it to their destination without harm. In that case, a state of affairs in which no lives are lost is the actual state of affairs associated with following the order. But it is quite possible that a reasonable person would have foreseen an entirely different outcome: perhaps such a person would have expected the ship to be made seaworthy but only at the loss of the lives of, say, ten percent of the crew. In that case, such a state of affairs is the reasonably-expected. It is possible, however, that when we turn to all acts of following a captain's order to stay the course when the crew believes this to be certainly disastrous, and not just the particular act of that sort contemplated by the defendants in Ashton, we find, for instance, that it is usual for half the crew to be lost and half to reach their destination. Thus, the usual state of affairs associated with following the order could be a state of affairs in which half the crew is lost. As this example illustrates, although the reasonably-expected and the usual are sometimes the same, it need not be so. To determine what is included in the category of the proscribed-to-avoid we look to the full set of acts of refusing to follow an order, and this includes states of affairs radically different from any that are otherwise involved in Ashton. It includes, for instance, the states of affairs realized by sailors who desert 
during time of war, sailors who impertinently refuse minor duties, and sailors who aim to undermine the authority of senior officers.

We have potentially a host of distinct states of affairs associated with the action the defendant actually performed and a host of distinct states of affairs associated with omission of the action. It is clear that at the very least, the defense requires a claim to the effect that at least one of the states of affairs associated with the action is superior to at least one of the states of affairs associated with the omission. But which needs to be compared to which? Do we compare the actual associated with the act with the actual associated with the omission, thus asking whether the defendant actually made the world better by acting? Perhaps we compare the usual associated with the act with the proscribed-to-avoid, thus asking whether holding the defendant criminally liable would amount to prohibiting a set of acts, one of which is the defendant's, that are, when aggregated, of greater value than disvalue? Alternatively, do we need to aggregate the values of some of the associated states of affairs on one side or the other before comparing them? If so, which need to be aggregated and how? Instead, might it be that what is to be compared are things that are not on our list at all? There are no settled answers to these questions to be found in the law. Let us consider some examples.

In the well-known case of Burrough of Southwark $v$. Williams, in the middle of a housing shortage in London, the homeless defendants squatted in some unoccupied houses owned by the Burrough. ${ }^{12}$ As the houses were standing empty anyway, squatting caused little or no injury to the Burrough, although it did violate the Burrough's property right, while not squatting would have resulted in terrible suffering on the part of the defendants from living on the street. In rejecting the defendants' necessity defense, the court makes the following remark: "If homelessness were once admitted as a defence to trespass, no one's house could be safe. Necessity would open a door which no man could shut. It would not only be those in extreme need who would enter... There would be others who would imagine that they were in need, or would invent a need, so as to gain entry. Each man would say his need was greater than the next man's. The plea would be an excuse for all sorts of wrongdoing." 13 The court should be understood to be weighing the evils that laws against trespass are aimed at minimizing, including violations of property rights by individuals who have no need to violate them, and violations by individuals who have further pernicious aims beyond those of the violation itself, against the evils of homelessness generally. This is to compare the proscribed-toavoid associated with the defendants' act with the usual associated with its omission.

Courts are far from consistent, however, in making this particular comparison. The formulation of the defense in the Model Penal Code does not suggest that this is the appropriate comparison to be made. The relevant section reads as follows: "(1) Conduct that the actor believes to be necessary to avoid a harm or evil to himself or to another is justifiable, provided that: (a) the harm or evil sought to be avoided by such conduct is greater than that sought to be prevented by the law defining the

\footnotetext{
12 See 2 All E.R. 175 (1971).

${ }^{13}$ Cf. Matthew Hale, The History of the Pleas of the Crown (Philadelphia: 1847), prt. 1, ch. 9, p. 54.
} 
defense charged." 14 The Model Penal Code seems to be directing us to compare, not the usual, but the expected associated with the omission, the "harm or evil sought to be avoided by such conduct," with the category of what is proscribed-toavoid. ${ }^{15}$ However, even courts in jurisdictions that have adopted the language in the Model Penal Code in a statutory formulation of the defense have sometimes made neither the comparison between the usual and the proscribed-to-avoid nor the comparison that the Model Penal Code seems to be encouraging between the expected and the proscribed-to-avoid. In State v. Cozzens, for instance, the defendants were charged with trespassing at an abortion clinic and offered the necessity defense claiming that given their belief that life begins at conception, trespass was necessary to prevent the deaths of the fetuses carried by the women whom they prevented from entering the clinic. ${ }^{16}$ The court rejects the necessity defense in part on the grounds that although the defendants thought their acts were preventing abortions, they did not know of any specific scheduled abortions which they were preventing through their acts.

We may wonder why the court should require specific knowledge of this sort. If a person trespasses in order to put out a fire, he does not need to be capable of identifying any particular person who would have been harmed by that fire in order for his necessity defense to succeed; it is enough to have known that some people would have been harmed. Why should specific knowledge matter in this case? A clue can be found in the fact that the court notes that the clinic offered other gynecological services and, for all the defendants knew, the women they prevented from entering were not intending to have abortions. The idea seems to be that since, for all the defendants knew, they were preventing very few abortions, or even none, through their protest, the state of affairs associated with the trespass might have had no great value.

The court in Cozzens is clearly not comparing the usual associated with not trespassing with something else, since then it would need to consider not just the abortions that the trespass actually prevented, and the court mentions that there were fourteen scheduled for that day that had to be rescheduled or cancelled, but abortions prevented by similar protests at different times or places. Nor, given that it admits that many abortions were in fact prevented by the protest, is the court considering the actual associated with omission of the trespass. Similarly, the court is not looking at the expected since the defendants in fact thought that they were preventing some fairly large number of abortions, although they probably had no specific number in mind. The court seems to be looking, instead, at the reasonablyexpected associated with the omission. The court's idea seems to be that given that the clinic offered many services, a reasonable person would not have expected to be preventing any abortions, or, at least, anywhere near as many as the defendants thought they were preventing, or even actually prevented.

These are just a few examples, but they are representative of the large variance that we find in necessity defense cases. Courts make importantly different kinds of

\footnotetext{
14 Model Penal Code, s. 3.02.

15 Ibid.

16 See 241 Neb. 565, 490 N.W.2d 184 (1992).
} 
comparisons from case to case. One moral that we might draw from this is that there is simply a great deal of confusion in the courts about what to compare to what when applying the necessity defense. However, there is a different moral to draw. Perhaps different things are properly compared in some cases than in others. This is not to say that all necessity cases have involved the right comparisons, but, instead, that the mere fact of diversity that in one case the usual is compared to the proscribed-to-avoid, and, in another, the actual associated with the act is compared to the reasonably-expected associated with the omission, for instance, does not indicate mistake on the part of the courts. It might indicate that the fundamental purposes of the necessity defense are served by making one kind of comparison in one case and another in another.

While we need to be open to the possibility that the courts are confused, and therefore open to the possibility that some set comparison is the right one to make across the board in determining if the defendant's act was better than the alternative, it is worthwhile to consider what we discover about the defense if we take this alternative moral from the diversity of comparisons that we find in the case law. In what follows, we will, as a working hypothesis, take this to be a further feature of the necessity defense that needs to be accommodated by a proffered rationale for the defense. In adjudicating the claim that the defendant's act was better than the alternative, a comparison between two sorts of things might be the correct one to make in one case, even though a comparison between two significantly different things is correct in another. We can confront proposed rationales for the necessity defense both with this fact and the fact that the evaluative standards not of the defendant but of the legislature are to be employed in evaluating the alternatives. If we find that a rationale cannot accommodate them, then we have some motive to seek an alternative rationale.

\section{Necessity as Justification}

To say that conduct is justified is to say that it is not wrongful. The idea is that when conduct is justified it is something about the conduct, as distinguished from something about either the agent who performed it or something about the way in which it was performed, that makes punishment of it inappropriate. If conduct is justified, then when we consider the totality of legal rules, taking into consideration tacit exceptions written into the rules and considering which rules trump which, we find that conduct of the sort that we have before us is not actually prohibited. ${ }^{17}$

There are three different ways in which a theorist can reach the conclusion that the necessity defense is a justification. All three ways involve some tacit premise about the nature of legal prohibition. According to the moral privilege view, the necessity defense blocks criminal liability because people who choose the best of their alternatives are thereby choosing what morality would have them choose. Under the moral privilege view, since to choose the best of our options is not morally wrongful, thinks the advocate of this position, it is not legally wrongful.

${ }^{17}$ See Claire Finkelstein, "When the Rule Swallows the Exception," Quinnipiac Law Review 19 (2000). 
The tacit premise is this: conduct is not legally prohibited if it is not morally wrongful.

According to the legislative intent view, to punish people who choose the best of their options is to undermine the intent of the legislature in passing the statute under which the defendant is charged. Under the legislative intent view, since to choose the best of our options is not to choose in a way that the legislature aimed to discourage, thinks the advocate of this position, such conduct is not legally prohibited. The tacit premise here is this: conduct is not legally prohibited if punishment of it would be contrary to the legislature's intent.

According to the legislative standards view, to punish individuals who choose the best of their options is to act contrary to the standards for the evaluation of conduct accepted by the legislature. A person's standards of conduct might run counter to her intentions. We often intend to do things that we think, in our heart of hearts, to be unacceptable. Likewise, the legislature, too, can intend to punish something that, by its own standards of evaluation, is perfectly acceptable, even if it does not explicitly recognize it as such. Under the legislative standards view, since to choose the best of our options is not to choose in a way that the legislature disapproves of, even if it does indeed intend to punish such conduct, thinks the advocate of this position, such conduct is not legally prohibited. The tacit premise here is this: conduct is not legally prohibited if it meets the legislature's standards of acceptability.

The tacit premises involved in these three efforts to explain the sense in which the necessity defense is a justification involve claims that are familiar from the jurisprudential literature both on the nature of law and on the interpretation of legal texts. It is thus little surprise that the well-known necessity case of Regina v. Dudley and Stephens, in which the shipwrecked defendants killed and ate one of their innocent lifeboat mates in order to save their lives, is standard fare in courses on jurisprudence. ${ }^{18}$ These tacit premises are deeply controversial and all of them are at the very least in need of many qualifications if they are even to approximate the truth. However, what is striking is that even if we grant these tacit premises, the necessity defense does not appear to be a justification for any of the three reasons offered. Let us consider them in turn.

The moral privilege view has two problems, the second of which is more serious than the first. First, on that view, it is difficult to explain the pride of place that we give to the legislature's evaluative standards in determining whether the defendant's act was indeed the lesser evil. If the court in Leno, the hypodermic needle exchange case, had judged that morality required or permitted distribution of the needles without prescription, why would it defer to the legislature's opinion to the contrary? If the moral acceptability of conduct establishes that it is not legally prohibited, as we are granting for the sake of argument, then the court should not substitute anyone else's opinion about what morality requires for its own. It is possible that a proponent of the moral privilege view can overcome this difficulty, since we can imagine an account of the proper separation of powers of the government according to which the judiciary is barred, for some reason, from employing its own moral

${ }^{18}$ See $14 Q B D 273 D C(1884)$. 
standards, even though morality dictates legality. Perhaps such an account will do, though it is doubtful since deference to the legislature's evaluative standards would be correct in the application of the necessity defense even in systems that divided up the powers of the government differently from this.

However, there is a second and more serious problem with the moral privilege view: the necessity defense seems to apply properly even in cases in which we do not distinguish on the basis of morality between the defendant's act and the omitted alternative. Let us assume that the proverbial driver who runs a stop sign in the middle of the desert, where he can see perfectly well that no one will be endangered by his doing so, has committed a crime but has not committed a moral wrong. Even under that assumption, however, if he runs the stop sign in order to rush someone to the hospital, someone he believes will die were he to stop, he has not only not committed a moral wrong, he is no longer criminally liable, for he has a necessity defense. Since it was not moral wrongdoing in the absence of the elements of the necessity defense, their presence cannot undo the defendant's criminal liability by undoing his moral wrongdoing; the moral status of the act does not change in the face of the necessity of the act. This is a trumped-up example, but the point is clear even in paradigm necessity defense cases. If we consider Ashton again, it is far from clear that we have any opinion on the basis of morality about what the sailors should have done. Failing to obey an order is not, in itself, moral wrongdoing. It depends, at least, on what they were ordered to do. Furthermore, had the sailors simply deferred to the judgment of their captain, who had no more interest in dying at sea than they, they might have been foolhardy or excessively deferential, but they would not have committed a moral wrong. What that shows is that they cannot shield themselves from criminal liability on the grounds that their conduct was not morally wrongful. It would not have been morally wrongful of them to refrain from revolting either.

Even defenders of the view on offer, however, who think that every violation of the law is, on those grounds, an instance of moral wrongdoing cannot accept the moral privilege view. The problem for them is one of circularity. If the running of the stop sign is a moral wrong because and only because it is a violation of the law, then the criterion of moral wrongfulness is not sufficiently extra-legal to allow for a rationale from a proponent of the moral privilege view for the necessity defense. To know if the person who runs the stop sign in order to rush someone to the hospital is deserving of a defense, we would need to know if what he did was morally wrongful. But to know that, we would need to know, among other things, if what he did was prohibited by the law, since violation of every prohibition is thought to be morally wrongful. But to know that we would need to know if he is deserving of a necessity defense, since, after all, if he is deserving of a defense, on the view on offer, then he is not actually violating a prohibition. But that is the question we began with.

The problem with the legislative intent view is that under it there would be nothing legally objectionable about a regime in which the legislature were to explicitly deny the necessity defense to certain defendants while acknowledging that the defendants' acts were better than the alternative. If legislative intent governs, then legislative intent governs. If the legislature specifically chooses, for instance, not to grant a necessity defense to a charge of destruction of property when the 
property destroyed prevented the destruction of much more property, then so be it. There would be nothing legally objectionable about that. This is problematic since there manifestly is. There is more to the point here than the familiar one that since legislatures can have morally bad intentions, in deferring to them, the judiciary can find itself implementing morally bad law. The point is more serious than that in the current context. The point is that someone who takes the rationale for the necessity defense to be that it enables the enactment of legislative intent cannot see there as being anything legally objectionable about a failure to grant the necessity defense when the legislature intends not to grant it, even though its elements are in place. Thus under the legislative intent view, the defense's applicability is dependent on the wrong thing. It is dependent on the content of legislative intention, where the defense is more deeply rooted than that. Law itself requires it, even if the legislature maintains that it can be dispensed with in a particular case. The legislature, it seems, can be wrong about what the law requires in this arena. To put the point another way, the necessity defense can be legitimately constructed even by a judge in a purely civil system that has no statutory provision for it and that has no common law history of its use. It is something that a judge, restricting himself to the roles of discoverer and interpreter and eschewing any law making, can nonetheless appeal to independently of legislative intent.

We may well ask what evidence there is for this and why we should accept that it would be a legal mistake to deny the necessity defense to a particular defendant when its elements are in place, even though the legislature explicitly intends to deny it to defendants of that sort. One way to approach this is by imagining a case in which the intentions of the legislature clearly diverge from the evaluative standards it promotes: the legislature explicitly intends to punish some defendants even when their acts are, by the legislature's own standards, optimal. The legislature in such a case is at once committed to maintaining that the defendant did the best thing he could do and that he should be nonetheless punished. When we feel outrage toward the legislature's demand in a case like this, we are likely to express it by noting the hypocrisy involved. There seems to be some conflict between admitting that the defendant chose optimally and insisting that he be punished for doing so. We are likely to see this conflict even if we disagree with the legislature's evaluative assessment. Imagine, for instance, that the law requiring prescriptions for the distribution of needles asserts both that the spread of AIDS is worse than unprescribed uses of needles and that the necessity defense is not to be granted to anyone who prevents the spread of AIDS by distributing needles without prescriptions. If we think that the unprescribed use of needles is actually much worse than the spread of AIDS, we might still criticize the law on the grounds of internal inconsistency. But there can only be internal inconsistency in the law in such a case if there is legal pressure to grant the necessity defense whenever its elements are avowedly in place, pressure that derives from some source distinct from legislative intent.

The legislative standards view provides a clean explanation for the fact that the legislature's standards of evaluation trump other evaluative standards in determining if the defendant did, indeed, elect the best of his alternatives. After all, under the legislative standards view, what the defense does is to show that the defendant's 
conduct was not prohibited because it does not fall short of the legislature's standards. If we accept, as we are doing for the sake of argument, that what is legally prohibited often depends on the legislature's standards, then a central strand of thought in the understanding of the lesser evils requirement by courts is explained. However, the legislative standards view still faces an insuperable problem. The problem is that there is good reason to think that the necessity defense was rightly found in the law even when there was no evidence sufficient to establish that the legislature's standards were as they would have had to have been for the legislative standards view to be correct.

To see this, let us suppose that we are trying to determine what a person's standards are and we start by considering the fact that he sometimes says, "It is wrong to do a particular thing." He does not just say this, moreover. He also disapproves of others who do it, feels guilt when he does it, takes more laborious routes to his goals in order to avoid doing it, and perhaps engages in other behavior that indicates that he takes himself and others to have fallen short in some way when they do it. Up to this point, we have no reason whatsoever to place any qualifications on the claim that the person accepts standards that people fall short of meeting when they do what he says is wrong. There is no "unless" clause in this characterization of the person's standards. We may ask then what would lead us to hold that he actually accepts standards that a person can comply with when he does the condemned action, as long as some other condition is also met. There are two broad categories of behavior and attitudes that could lead us to this conclusion. It could be that the person sometimes says things like "It is wrong to do a particular thing, unless another condition holds," or fails to feel disapproval of those who do the particular thing when the other condition also obtains, fails to feel guilt when he himself does the condemned thing when the other condition is true, and does not make any effort to avoid doing the wrongful thing when the additional condition is met. There might be, then, evidence from the person's behavior that his standards include the relevant exception. Alternatively, in the absence of such evidence, we might know something about the reasons that he has for taking the particular action to be objectionable, and we might be able to see that when the exception is met the reasons are absent or nullified. We might, for instance, know that he takes others to have fallen short of standards when they touch others, because he thinks people should have autonomous control of their own bodies; since when there is consent to be touched touching fails to be a violation of autonomy, the person is probably best characterized as holding that it is wrong to touch another without consent, and not merely that it is wrong to touch another.

It is worth considering if we could we have either kind of evidence to suggest that when the legislature formulates a criminal prohibition the standard of conduct that it accepts actually contains a tacit "unless" clause. Evidence of the first sort is available, since we have no shortage of case law in which the necessity defense has been granted. However, the necessity defense was developed in cases like Ashton and judges in the cases did not have the benefit of judicial decisions and legislative proclamations to appeal to in rationalizing their view that the defendants in their cases acted in a way which was acceptable relative to the legislature's standards. We may then ask if they did have, or if we do we have, evidence of the second sort. Did 
they, or do we, have evidence to suggest that the reasons accepted by the legislature for which criminal prohibitions are enacted are absent or nullified when the elements of the necessity defense are in place?

In answering this question, there is a line we must carefully walk. It is not generally the case that the fact that the reasons for which a criminal prohibition is in place are absent shows that the conduct in question is justified. Speeding is prohibited in order to promote safety, but it is in violation of the legal norm to speed even in conditions in which it is perfectly safe. Yet, as noted earlier, the necessity defense can have place even for offenses of this kind, as when it is employed in defense of a speeding charge by a driver rushing someone to a hospital. If the necessity defense works by indicating that the reasons for prohibiting conduct of the sort that the defendant engaged in are absent or nullified when its elements are satisfied, it must do so without extending the scope of justification beyond where we ordinarily take it to extend. There must be something special about the particular reasons that are absent when the defendant did the best he could that does not attend other reasons for prohibitions, like the reasons for prohibiting speeding.

The problem with the legislative standards view is that it does not allow us to walk this line. Even if the advocate of the rationale can discharge the burden of identifying what is special about the reasons for prohibitions that are absent when the defendant chose the best option, he cannot explain why that special feature serves to provide a justification in those instances and not in others where that special feature is absent. He cannot provide this explanation because he is committed to the claim that every kind of conduct which is acceptable by the legislature's standards is thereby justified. The problem is that if the reasons for a prohibition suggest that every time such reasons are absent there is an exception to the prohibition, then there is too much included in the legislature's standards for it to be the case that every act which is not wrong relative to them is justified. Under that assumption, which is needed to get the rationale on offer off the ground, there simply cannot be a tacit "unless" clause for every standard to which the legislature is committed.

Perhaps the clearest evidence of the irresolvability of this problem comes from the fact that if there were such a tacit "unless" clause in every case, nearly every inchoate crime would be justified. Attempts, for instance, are prohibited because there is something bad about completion; if murder were not worth proscribing, then neither would attempted murder be. But that implies that in every case of a failed attempt, one of the primary reasons for prohibiting the defendant's behavior is absent. In such cases, we do not have a realization of the thing that we proscribe the attempt to prevent. If we can thus conclude that a prohibition of the form "Do not attempt to kill" is actually more accurately expressed by saying "Do not attempt to kill unless death does not occur," then it follows that failed attempts are always justified. This cannot be right.

The same argument applies, perhaps even more clearly, with respect to the other inchoate crimes. Let us consider solicitation. We prohibit solicitation because we recognize something worthy of prohibition about the crime solicited; the reasons for prohibiting solicitation derive their force from the reasons for prohibiting the solicited crime. This is part of the reason that there is no crime of solicitation when 
the acts solicited are not in fact criminal, even if believed by the solicitor to be. But then every time there is solicitation without the crime solicited, as when the hit-man the defendant paid gets cold feet before taking any steps, the reasons for prohibiting solicitation are absent. Yet solicitation in such cases is not justified. In a case like Ashton, before there is a track-record of using the necessity defense, there is no evidence to suggest that the legislature does not intend punishment for defendants like the one before the court, and hence no evidence of that sort to suggest that the defendant's conduct lives up to legislative standards. But, nether is there acceptable evidence to suggest that the reasons for the prohibition do not apply to conduct like the defendant's, because whatever evidence of that sort that we can find extends promiscuously to cases where there is clearly no justification, such as in inchoate crimes. But then it appears that under the legislative standards view, a court like the Ashton court has no grounds for acquittal. That is manifestly wrong. There are good grounds for acquittal in that case, and so what follows is that the legislative standards view is inadequate.

There remains the logical possibility that the moral privilege view, the legislative intent view and the legislative standards view do not exhaust the options for rationalizing the necessity defense in a way that shows it be a justification. Perhaps there is another road. The failure of the three most natural and obvious ways of reaching that conclusion, however, suggests that we ought to be less sanguine that we have been in asserting that the necessity defense is a justification.

\section{A Procedural Defense}

The view we should take is that the necessity defense is a procedural estoppel defense: when a defendant's act is the best of the alternatives, punishment by the government would involve the government in internal inconsistency analogous to that involved in double jeopardy. Whenever we assert that the government has acted inappropriately in a way which warrants granting a defense on those grounds to a defendant, or would do so were the state to punish, we have in mind, explicitly or implicitly, some standard of conduct that we take to have legal status and with respect to which the government has fallen short. When we say, for instance, that the defendant has diplomatic immunity, the standard of conduct is set by the government's agreements with the diplomat's nation. The agreements set a standard by which the government's conduct with respect to the defendant is to be judged. The case for thinking, then, that any particular defense is procedural proceeds in two stages: first we have to identify a legally binding standard by which government conduct is to be judged, and, second, we have to show that the government's conduct would not meet that standard were it to punish when the elements of the defense in question are in place. These two stages will be followed here. The relevant standard of government conduct is set by the reasons that citizens have to consent to the punishment of some people under the statute the defendant is charged with violating. The government would fail to live up to this standard were it to punish the defendant who chooses the best alternative because in such a case the 
reasons that citizens have to consent to the punishment of some under the statute are nullified or overridden.

Although in the end the point can be made in a way which is neutral with respect to any particular conception of the source of legitimate state power, it will be helpful to situate the position to be defended here within a consent-based theory of political obligation. According to all such theories, the state's power to govern is granted to it by the consent of citizens to be governed. Thus, on such views, the state's power derives from the power that each citizen has over himself. Central to such views is the further requirement that the state has no legitimate power deriving from coerced consent. The state has no authority to act in a way which is unsupported by the reasons that citizens have to consent to be governed by state power in the first place. Thus, on a consent-based theory of political obligation, the reasons that citizens have to consent to subjection to state power provide a standard by which we can judge the acceptability of state action: if a course of conduct by the state is not one that citizens would have reason to consent to then it is not a legitimate use of state power. When punishment by the state is what is at issue, it is legitimate only if citizens would have reason to consent to it.

The notion of having a reason is one of the most slippery to be found in moral and legal philosophy. However, this much is, if not clear, then at least sufficiently defensible to warrant asserting it without defense: a fact provides a person with a reason to do something only if the fact counts in favor of doing the action. If this is true, then we have the following standard by which to judge a punishment by the state: if the facts that count in favor of the punishment fail to warrant citizen consent to it, then the punishment would amount to state misconduct. The question, central to the necessity defense, of whether the defendant's conduct was the best of his alternatives just is the question of whether there is sufficient reason for citizen consent to the punishment of that conduct. The idea of the lesser evil or the best option has no relevant content independently of the question of what citizens can consent to punish. Those concepts are the law's way of directing judges to the question of whether punishment would amount to state misconduct because citizens lack sufficient reason to consent to the punishment; if it would, then the defendant's act was the best of his options, or the lesser evil; if not, then not. "Best," in this context, just means given the alternative, citizens lack sufficient reason to punish it.

The reasons that could serve to support citizen consent to punishment of a certain sort of conduct are very diverse, as can be seen by considering just some of the examples discussed so far in this paper. What reasons do citizens have to consent to the punishment of soldiers who fail to follow orders? Citizens have a diversity of reasons for wanting an orderly military, and they also have a diversity of reasons for wanting to defer to the military leadership, within reason, about the means that need to be undertaken to make the military orderly. On the one hand, citizens can consent to punishing failures to follow orders so that soldiers will fire in the direction they need to fire to protect home and country, for instance. But, citizens can consent to such punishment, on the other hand, to support the choices of the military about how they are to operate. What reasons do citizens have to consent to the punishment of trespassers? The clear but highly diverse considerations of harm, insecurity, and property rights violation come to mind. What reasons do citizens have to consent to 
punishment of the distribution of hypodermic needles without prescriptions? A yet distinct set of diverse considerations pertaining to health safety, to the minimization of drug addiction, and to the protection of those whose capacity to make thoughtful judgments about injections is impaired or absent might be appealed to.

We find patterns of reasons across these different areas: considerations of bodily integrity, health, and autonomy provide reasons for consent to punishment for conduct that threatens them in a variety of very diverse ways, for instance. But there is little reason to expect there to be codifiable principles that can provide us with a decision procedure for determining whether there is sufficient reason to consent to punishment of a type of conduct independently of the details pertaining to the type of conduct under discussion. The discussion must be undertaken, more or less from scratch, with respect to each type of conduct. In each case, the discussion is as potentially unbounded as political morality itself.

The tangle of issues in political morality pertaining to the kind of conduct that the defendant is charged with is in play in every necessity defense trial. As is often the case in arguments about reasons, to justify denying the defense, a judge may only need to cite a single reason in favor of citizen consent to punishment together with a claim to the effect that that reason is sufficient. Alternatively, on the other side, a judge may only need to cite a single sufficient reason against such consent in order to justify acquittal. Given the diversity of reasons that can form the basis of citizen consent to punishment, we should not expect there to be uniformity in the kinds of reasons that judges cite in particular cases. We ought to expect judges to compare different sorts of states of affairs associated with the defendant's act or its omission in different cases depending upon which are particularly crucial to the question of reasons for citizen consent to punishment. Any kind of comparison between states of affairs associated with the act or omission, between, say, the reasonably-expected associated with the act and the proscribed-to-avoid, or between the actual associated with the act and the usual associated with the omission, is potentially important for determining what reasons there are, or are not, for citizen consent to punishment of the defendant's act; one comparison might be relevant in one case, and irrelevant in another.

Let us consider two examples of ways in which the particular interests that citizens have in prohibiting a certain kind of conduct can make a certain sort of state of affairs associated with that conduct salient to the necessity defense. First, there are crimes that are not harmful individually but only in aggregate. Any individual act of littering does little damage, but when there is enough littering there are a variety of undesirable aesthetic and health-related results. If a defendant who is charged with littering offers the necessity defense, because the aggregate harms of littering are among the reasons that citizens have to consent to punishments for littering, the aggregate harms of the defendant's act and the omission of it will be peculiarly salient here. Thus, the usual associated with the act and the proscribed-toavoid will be of particular importance. Conversely, both the actual and the expected will be irrelevant. The fact that a particular act of littering actually caused, or was expected by the defendant to cause, little harm is not important, since the actual and expected results of acts of littering are not among the reasons that citizens have to consent to the punishment of littering. 
By contrast, second, there are crimes that are individually harmful and where the harms in question are much greater when intended than the harms involved in unintended accidents with similar results. Intentional homicide, for instance, is harmful and is much more harmful than an accidental death, even when the loss to human life is the same. Here, the actual and the expected that are associated with the act are of particular importance for assessing a defendant's necessity defense. The actual matters, since part of the reason that citizens consent to the punishment of intentional homicide is because of what actually results from such acts considered individually. The expected matters also, however, because citizens also consent to the punishment of intentional homicide because such homicides involve a peculiarly repugnant attitude on the part of the killer that, at the least, exacerbates the harm. Similarly, if the crime in question were a crime of negligence, where consent to the punishment of such behavior is strongly tied to the thought that the agent failed to do what the reasonable person would have done, then the reasonably-expected will be crucial. The point is that when we see what the guiding issue is in the necessity defense, the question of the acceptability of government conduct relative to the reasons that citizens have to consent to it, we see that we should actually expect correct application of the defense to lead to the diversity of approaches that we find in the case law.

When a valid statute specifies punishment for some sort of conduct, the courts, other, perhaps, than courts that are asked to interpret a constitution, are required to hold that it is possible for conduct to be justifiably punished under the statute. Courts must assume that there is some conduct meeting the description offered in the statute such that punishment of it would not amount to state misconduct. Therefore, courts are required to assume that some tokens of the type of conduct described in the statute are such that citizens have sufficient reasons to consent to their punishment. What this implies is that a court that honors a necessity defense cannot identify reasons against citizen consent to punishment that would imply that no conduct was justifiably punished under the statute. The court needs to identify reasons that distinguish punishment of the defendant from punishment of others who are charged under the statute. What the court is searching for is a way in which the very reasons that warrant citizen consent to the punishment of some individuals under the statute are overridden or fail to apply to the defendant before the court. This is why the court is to defer as much as possible to the evaluative standards of the legislature. The issue is not whether the statute under which the defendant is charged is appropriately supported by citizen consent; it is assumed that it is. The issue is, instead, whether there is consistency between consent to the statute and consent to the punishment of the defendant.

This is also why the defense is a procedural estoppel defense. A court that honors the necessity defense is saying that the very reasons that underlie citizen consent to the legislative act of enacting the statute fail to provide sufficient support to citizen consent to the judicial act of punishing the defendant. Just as the defense of double jeopardy works by showing that trying the defendant would involve inconsistent commitments on the part of the government, a commitment to its own authority to settle questions and a commitment to ignoring a prior exercise of that authority, the necessity defense works by showing that punishment of the defendant would 
involve an inconsistency in government authority. Were the government to punish, then either the legislative act of passing the statute or the judicial act of punishing would be unsupported by citizen consent and so illegitimate.

It is important to see the difference between this proposed rationale for the necessity defense and the rationales discussed earlier. In the last analysis, it is possible that any rationale for a criminal defense will have to appeal to the conditions of legitimacy of exercises of state power. Even the moral privilege view may ultimately rest on a claim to the effect that the state is acting unacceptably when it punishes someone who has committed no moral wrong. But what does the work in rationalizing the defense, for views such as that one, is not a direct appeal to a standard by which state conduct is to be judged, but an appeal, instead, to a principle to the effect that punishment requires moral wrongfulness. We might justify that principle by appeal to the requisite conditions for the legitimacy of state power, or we might not; the view of the necessity defense as such is neutral on the question of how that principle is to be justified. Perhaps it is to be justified by appeal to the concept of punishment or the concept of law, or by a proposed link between civil law and divine law. By contrast, the approach proposed here allows us to identify a direct link between the presence of the elements of the necessity defense and the illegitimacy of the use of state power to punish.

The rationale proposed here bears an interesting relationship to the legislative intent and legislative standards views. While such views are wrong, for the reasons described earlier, they get something right. It is because of the fact that there is no reason to discourage the sort of behavior that defendants engage in when they have necessity defenses that we grant those defenses. Those two views, then, are suggestive of what facts actually rationalize the necessity defense. Legislative intent and legislative standards are notions that track, in complicated ways, the underlying reasons that support citizen consent to exercises of government power. The view offered here, however, takes the presence of reasons to punish to be a necessary condition of the legitimacy of exercises of state power, independently of the legislature's intentions or standards. What this implies is that the view described here accommodates the fact that the legislature may intend to use power in a way which is illegitimate and when it does there is legal pressure on judges to act contrary to legislative intent rather than in line with it. Similarly, not just any reasons for a prohibition are of relevance to the question of the conditions under which the government should punish violation. It is not the case that every time the reasons for prohibiting conduct are absent, the conduct in question is not legitimately punished. Instead, a particular set of reasons are of importance: reasons that can form the basis of citizen consent to punishment. These are the points that are not found in the views discussed earlier. The absence of reasons to punish is of relevance to the necessity defense not because it shapes the content of legal prohibitions, but because it delimits the boundaries of the legitimate use of state power against the very citizens from whom the state draws the legitimacy of its power in the first place.

A person who chooses the best of a series of bad options is often the object of our sympathy and even our admiration. We would not want to have faced the tough choice he faced, and we sometimes hope that we ourselves would have been strong 
enough to choose, as he did, the lesser evil. When we read about such people in stories, we root for them and hope that they will triumph, as the Library Lion does in the end, over people who try to use the rules against them. Where we find people who are objects of sympathy and admiration, we often also find people who have acted as morality would have them act. Thus we naturally conclude that the withdrawal of criminal liability from such people, our refusal to punish them, is rooted in and justified by the very facts about them in virtue of which they are to be morally admired. What has been shown here, however, is that this is not so. Very often people who act under necessity are to be admired. Very often they have done as morality would have them do. But it is not this that makes it proper for the state to refuse to punish them. It is proper for the state to refuse to punish because state power is only to be used where it can be supported by citizen consent. In the absence of this, punishment is an abuse of state power. This provides a standard by which state action can be judged, and it is a standard that punishment by the state does not meet when the elements of the necessity defense are in place. The defense is deeply rooted, not in our moral thought, but in our thought about the very nature of legitimate state power, and its roots are so deep, in fact, that even a child's appreciation of the grounds of legitimacy of punishment under the rules is enough to make us see that the state, or, really, any broadly representative rule-making authority such as the library, is acting wrongly when it punishes people who do their best. ${ }^{19}$

\footnotetext{
${ }^{19}$ I would like to thank Claire Finkelstein, Steve Finlay, Doug Husak, and Scott Shapiro for comments on earlier drafts, and Bridget Asay, Civil Appellate Director for the Attorney General of the state of Vermont, for asking me if the Library Lion has a necessity defense.
} 